\title{
PENGARUH KOMITMEN ORGANISASI TERHADAP KINERJA KARYAWAN PERUM BULOG DIVISI REGIONAL KALIMANTAN SELATAN KOTA BANJARMASIN
}

\section{Annisa Ratu Mulianti}

Sekolah Tinggi Ilmu Administrasi (STIA) Amuntai

E-mail: annisa_ratu@yahoo.com

\begin{abstract}
Influence of Organizational Commitment on Employees Performance Public Corporation BULOG Regional Division South Kalimantan in Banjarmasin City. This study aims to determine the effect of organizational commitment on employee's performance in Public Corporation BULOG Regional Division South Kalimantan in Banjarmasin City. The research method uses a quantitative approach to the study sample size of 34 employees of Public Corporation BULOG Regional Division South Kalimantan in Banjarmasin City tested using simple regression analysis with software Statistics Programme for Service Solutions (SPSS) version 20.0. The study, of 34 permanent employees who work in Public Corporation BULOG Division South Kalimantan Banjarmasin, found that organizational commitment and significant positive effect on employee performance. Based on the results of this study concluded that organizational commitment is able to address concerns about the performance of employees in Public Corporation Bulog Regional Division South Kalimantan Banjarmasin. Implications of the study is expected to be a positive contribution to improving employee's performance and the performance of Public Corporation BULOG Regional Division South Kalimantan in Banjarmasin City and future research.
\end{abstract}

Keywords: organizational commitment, employee performance.

\begin{abstract}
Abstrak
Pengaruh Komitmen Organisasi terhadap Kinerja Karyawan Perum BULOG Divisi Regional Kalimantan Selatan Kota Banjarmasin. Penelitian ini bertujuan untuk mengetahui pengaruh komitmen organisasi terhadap kinerja karyawan pada Perum BULOG Divisi Regional Kalimantan Selatan Kota Banjarmasin. Metode penelitian menggunakan pendekatan kuantitatif dengan jumlah sampel penelitian sebesar 34 karyawan Perum BULOG Divisi Regional Kalimantan Selatan Kota Banjarmasin yang diuji menggunakan analisis regresi linear sederhana (simple regression) dengan software Statistic Programme for Service Solutions (SPSS) Versi 20.0. Hasil penelitian terhadap 34 orang karyawan tetap yang bekerja pada Perum BULOG Divre Kalsel Kota Banjarmasin, ditemukan bahwa komitmen organisasi berpengaruh positif dan signifikan terhadap kinerja karyawan. Berdasarkan hasil penelitian dapat disimpulkan bahwa komitmen organisasi mampu menjawab permasalahan mengenai kinerja karyawan pada Perum BULOG Divisi Regional Kalimantan Selatan Kota Banjarmasin. Implikasi penelitian diharapkan mampu menjadi kontribusi positif dalam meningkatkan kinerja karyawan dan kinerja Perum BULOG Divisi Regional Kalimantan Selatan Kota Banjarmasin dan penelitian yang akan datang.
\end{abstract}

Kata kunci: Komitmen Organisasi, Kinerja Karyawan 


\section{PENDAHULUAN}

Badan Urusan Logistik (BULOG) merupakan perusahaan umum milik negara yang menyelenggarakan ketersediaan beras nasional. Sebagai perusahaan yang mengemban tugas publik dari pemerintah, BULOG senantiasa melakukan kegiatan menjaga Harga Dasar Pembelian (HDP) gabah, stabilisasi harga pokok, menyalurkan beras untuk masyarakat miskin (Raskin) dan pengelolaan stok pangan. Ketersediaan beras yang bermutu, layak konsumsi, dan memadai bagi pemenuhan hajat hidup orang banyak merupakan tujuan didirikannya Perum BULOG. Tugas publik BULOG saling terkait dan memperkuat satu sama lain sehingga diharapkan dapat mewujudkan ketahanan pangan rumah tangga maupun nasional yang lebih kokoh. Realisasi tugas publik yang telah diatur dalam Peraturan Pemerintah salah satu diantaranya adalah BULOG bertanggung jawab dalam menyediakan dan menyalurkan beras bersubsidi bagi kelompok masyarakat berpendapatan rendah yang diwujudkan dalam pelaksanaan program raskin.

Program raskin yang dijalankan sering mengalami permasalahan dan hambatan. Pelaksanaan program raskin menunjukkan bahwa efektivitas program relatif masih lemah. Ketidaksesuaian data PPLS-11 dengan pagu alokasi sampai pada kegiatan distribusi yang dilakukan oleh karyawan merupakan bukti kaburnya dimensi kualitas dari kinerja karyawan.

Sasaran yang tidak sesuai dengan pagu alokasi dan kartu raskin yang juga tidak dibagikan merupakan bukti penyimpangan terhadap kuantitas distribusi raskin. Selain itu, proses sosialisasi dan transparansi yang

\section{Rumusan Masalah}

Apakah komitmen organisasi berpengaruh positif dan signifikan terhadap kinerja karyawan Perum BULOG Divisi Regional Kalimantan Selatan Kota Banjarmasin? kurang memadai mengindikasikan terdapat permasalahan mengenai kebutuhan akan supervisi. Lebih lanjut lagi, target penerima, harga, jumlah, dan frekuensi penerimaan beras yang kurang tepat serta biaya pengelolaan program yang cukup tinggi merupakan permasalahan yang berkenaan dengan efektivitas biaya. Jika dilihat dari segi kuantitas kinerja karyawan, pelaksanaan pemantauan pendistribusian beras belum optimal. Selain itu, mekanisme pengaduan yang kurang berfungsi juga merupakan salah satu bagian dari permasalahan mengenai aspek kualitas kinerja karyawan.

Fenomena yang terjadi dilapangan dimana banyaknya keluhan-keluhan dari masyarakat terhadap beras yang diperuntukkan bagi masyarakat miskin, diantaranya beras yang seharusnya dibagikan berkualitas medium ternyata tidak layak konsumsi. Peran potensial karyawan sangat dibutuhkan dalam mewujudkan efektivitas pelaksanaan program kerja. Melalui karyawan, perusahaan dapat memaksimumkan efektivitas dan memperoleh manfaat dari adanya sumber daya manusia yang berkualitas.

Berdasarkan pada fenomena, gejala, dan penelitian terdahulu yang telah dikemukakan diatas, maka penelitian ini mencoba untuk menguji secara empiris permasalahan mengenai "Pengaruh Komitmen Organisasi terhadap Kinerja Karyawan Perum BULOG Divisi Regional Kalimantan Selatan Kota Banjarmasin". Penelitian ini diharapkan mampu untuk memberikan kontribusi maksimal bagi keberlangsungan dan kegiatan operasional peruahaan serta meningkatkan keberhasilan kinerja karyawan secara optimal pada Perum BULOG Divisi Regional Kalimantan Selatan Kota Banjarmasin.

\section{Tujuan Penelitian}

Meneliti sebuah model teoritis mengenai kinerja karyawan dan melakukan pengujian empiris serta menganalisis pengaruh variabel independen terhadap 
variabel dependen dengan objek penelitian karyawan Perum BULOG maka, tujuan penelitian adalah menganalisis pengaruh komitmen organisasi terhadap kinerja karyawan Perum BULOG Divisi Regional Kalimantan Selatan Kota Banjarmasin.

\section{Manfaat Penelitian}

Penelitian ini diharapkan mampu memberikan kontribusi positif dalam hal implementasi atas hasil pengujian empiris terhadap variabel penelitian, dengan manfaat sebagai berikut:

\section{Manfaat Akademis}

Hasil penelitian yang dilakukan dapat dijadikan bahan masukan dan sumber referensi dalam bidang kajian manajemen sumber daya manusia.

Memberikan informasi yang relevan dalam bidang penelitian keilmuan khususnya yang berkenaan dengan perilaku organisasi.

Sebagai bahan perbandingan bagi penelitian terdahulu dan memberikan kontribusi serta saran untuk penelitian yang akan datang.

\section{Manfaat Manajerial}

1. Penelitian ini diharapkan mampu untuk menjadi kontribusi positif dalam hal meningkatkan kinerja karyawan Perum BULOG Divisi Regional (Divre) Kalimantan Selatan (Kalsel) yang berkedudukan di Kota Banjarmasin, agar dapat mencapai tujuan yang telah ditetapkan dengan di dukung oleh beberapa indikator penelitian dari variabel independen yaitu komitmen organisasi.

2. Dengan adanya penelitian mengenai komitmen organisasi karyawan pada Perum BULOG Divre Kalsel diharapkan dapat menunjang kegiatan operasional serta atmosfer kerja yang baik dan dapat meningkatkan kinerja karyawan.
3. Secara manajerial penelitian ini diharapkan mampu menjawab tantangan yang dihadapi Perum BULOG pada masa globalisasi, inflasi, dan fluktuasi ekonomi untuk tetap menjaga kestabilan harga pangan pokok rakyat, khususnya masyarakat miskin.

\section{TINJAUAN PUSTAKA \\ Landasan Teori \\ Konsep Komitmen Organisasi dalam Perilaku Organisasi}

Perilaku organisasi merupakan bidang ilmu terapan yang dibentuk berdasarkan kontribusi dari sejumlah bidang yang berkaitan dengan perilaku. Bidang-bidang yang utama adalah psikologi, psikologi sosial, sosiologi, dan antropologi. Komitmen organisasi merupakan fokus dari psikologi yang berusaha untuk mengukur, menjelaskan dan terkadang merubah perilaku individu (Robbins dan Judge, 2008). Keragamam perilaku individu inilah yang menjadi perhatian dari para ahli dan peneliti untuk dikaji secara lebih mendalam, karena dilatar belakangi oleh karakteristik yang berbeda. Lebih khusus lagi, komitmen merupakan salah satu komponen motivasi dengan mengintegrasikan teori komitmen dan motivasi akan didapatkan pemahaman yang lebih baik yang berimplikasi pada perilaku kerja (Meyer, Becker, dan Vandenberghe, 2004)

Komitmen organisasi merupakan komitmen seseorang terhadap organisasi tempatnya bekerja, komitmen seseorang terhadap organisasi merupakan salah satu jaminan agar kelangsungan kegiatan organisasi dapat terus berjalan. Komitmen organisasi sebagai suatu konstruk psikologis yang merupakan karakteristik hubungan anggota organisasi dengan organisasinya dan memiliki implikasi terhadap keputusan individu dalam hal melanjutkan 
keanggotaannya dalam organisasi (Allen dan Meyer, 1990).

Berdasarkan konsep komitmen organisasi dalam perilaku organisasi dapat disimpulkan bahwa komitmen organisasi merupakan ukuran kesediaan karyawan untuk bertahan dalam sebuah organisasi maupun perusahaan. Selain itu, komitmen karyawan terhadap organisasi adalah bentuk konsistensi diri dari seorang karyawan terhadap tanggung jawabnya dan tetap mempertahankan keberadaannya dalam organisasi, serta rasa memiliki terhadap perusahaan, menjalin hubungan baik antar sesama karyawan dan terus menjaga nama baik perusahaan.

\section{Konsep Kinerja Karyawan dalam Perilaku Organisasi}

Perilaku organisasi merupakan suatu studi yang menyangkut aspek-aspek tingkah laku manusia dalam suatu organisasi atau suatu kelompok tertentu. Perilau organisasi meliputi aspek yang ditimbulkan dari pengaruh organisasi terhadap manusia demikian pula aspek yang ditimbulkan dari pengaruh manusia terhadap organisasi (Thoha, 1983). Berbagai definisi mengenai perilaku organisasi selalu menitikberatkan pada perilaku manusia dan menekankan pada aspek-aspek psikologi dari tingkah laku individu. Bidang-bidang yang utama adalah psikologi, psikologi sosial, sosiologi dan antropologi. Kinerja merupakan bagian dari disiplin ilmu psikologi yang berusaha untuk menjelaskan dan memfokuskan bahasan pada perilaku manusia (Robbins dan Judge, 2008).

Kinerja adalah hasil atau tingkat keberhasilan seseorang secara keseluruhan selama periode tertentu di dalam melaksanakan tugas dibandingkan dengan berbagai kemungkinan, seperti standar hasil kerja, target atau sasaran, atau kriteria yang telah ditentukan terlebih dahulu dan telah disepakati bersama (Rivai dan Basri, 2005).
Kinerja karyawan merupakan hasil atas proses kerja yang terbentuk dari kegiatan dan tindakan karyawan serta praktik yang spesifik yang mengelola sekumpulan karyawan menjadi kelompok yang efektif, memiliki orientasi pada tujuan organisasi maupun meningkatkan laba perusahaan, dan produktivitas kerja.

Keberhasilan dan kesuksesan suatu organisasi ditentukan oleh kualitas sumber daya manusia baik pimpinan, manajer, dan karyawan yang menjalankan kegiatan operasional perusahaan maupun organisasi. Kaswan (2012) mendefinisikan kinerja sebagai suatu kegiatan karyawan yang mempengaruhi seberapa besar mereka memberi kontribusi terhadap organisasi. Karyawan memegang peranan kunci atas keberhasilan organisasi. Selain itu, pimpinan dan manajer juga memiliki peran dalam mengelola karyawan, unit kerja, dan seluruh organisasi guna menunjang kinerja organisasi.

Berdasarkan landasan teori yang dikemukakan oleh para ahli dapat ditarik kesimpulan bahwa kinerja merupakan suatu hasil kerja nyata, tindakan, dan implementasi dari rencana yang telah disusun dan berlangsung secara berkelanjutan guna menunjang kegiatan operasional perusahaan maupun citra dari sebuah organisasi.

\section{Penelitian Terdahulu}

Penelitian yang dilakukan oleh Memari et al (2013), dengan meneliti komitmen organisasi sebagai variabel bebas dan kinerja kerja karyawan sebagai variabel terikat. Penelitian yang dilakukan oleh Kashefi et al (2013) dengan menggunakan dua variabel yaitu komitmen organisasi sebagai variabel bebas dan kinerja organisasi sebagai variabel terikat. Penelitian yang dilakukan oleh Susanty dan Miradipta (2013) dengan menggunakan tiga variabel bebas yaitu sikap kerja karyawan, komitmen organisasi, dan 
kepuasan kerja sedangkan untuk variabel terikat hanya mengangkat variabel kinerja kerja karyawan. Penelitian yang dilakukan oleh Rafiei et al (2014) yaitu meneliti pengaruh komitmen organisasi terhadap kinerja karyawan. Mathieu dan Zajac (1990) meneliti pengaruh komitmen organisasi terhadap kinerja karyawan.

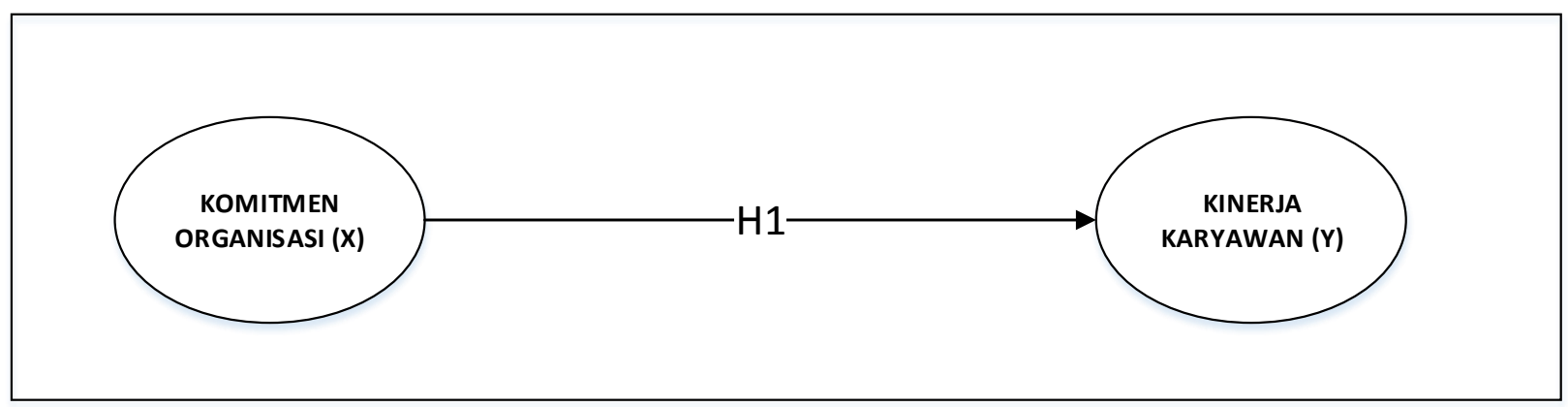

Pengaruh komitmen organisasi (X) terhadap kinerja karyawan (Y) Perum BULOG Divisi Regional Kalimantan Selatan Kota Banjarmasin

Sumber: Memari et al (2013), Suliman dan Lles (2000), Mathieu dan Zajac (1990), Susanty dan Miradipta (2013), dan Rafiei et al (2014), dan Ali et al (2011).

Keterangan:

$\mathrm{H}_{1}$ : komitmen organisasi berpengaruh positif dan signifikan terhadap kinerja karyawan Perum BULOG Divisi Regional Kalimantan Selatan Kota Banjarmasin.

$\mathrm{H}_{0}$ : komitmen organisasi berpengaruh negatif dan signifikan terhadap kinerja karyawan Perum BULOG Divisi Regional Kalimantan Selatan Kota Banjarmasin.

\section{METODE PENELITIAN}

\section{Jenis Penelitian}

Berdasarkan tujuan penelitian yang telah dirumuskan sebelumnya, maka jenis penelitian ini mengarah pada explanatory research.

\section{Lokasi Penelitian}

Lokasi penelitian bertempat pada Perum BULOG Divisi Regional Provinsi Kalimantan Selatan Kota Banjarmasin Jalan Jenderal Achmad Yani Km. 06 Nomor 561 Banjarmasin.

\section{Unit Analisis}

Unit analisis dalam penelitian ini adalah karyawan tetap yang masih aktif bekerja pada Perum BULOG Divisi Regional Kalimantan Selatan Kota Banjarmasin.

\section{Populasi dan Ukuran Sampel Penelitian}

Teknik pengambilan sampel menggunakan kategori nonprobability sampling dengan metode pengambilan sampling jenuh (sensus), dimana terdapat 34 orang karyawan tetap yang masih aktif bekerja pada Perum BULOG Divisi Regional Kalimantan Selatan Kota Banjarmasin.

\section{Pengukuran Variabel}

Pengukuran variabel menggunakan penggunaan skala sikap khususnya pendapat yang menggambarkan kehidupan maupun lingkungan seseorang. Skala yang digunakan dalam penelitian ini adalah skala likert dengan penggunaan data interval (Cooper dan Schindler, 2006).

\section{Teknik Pengumpulan Data}

Penelitian ini menggunakan teknik wawancara (interview) dan pembagian kuesioner. 


\section{Metode Analisis Data}

Metode yang digunakan dalam penelitian adalah metode kuantitatif. Beberapa analisis data yang digunakan meliputi uji kualitas data, uji validitas dan reliabilitas instrumen penelitian, analisis regresi sederhana, serta uji signifikansi. Pengujian seluruh data dalam penelitian menggunakan software IBM SPSS versi 20.

\section{HASIL DAN PEMBAHASAN}

\section{Hasil Uji Kualitas data Variabel}

\section{Komitmen Organisasi (X) dan Kinerja}

\section{Karyawan (Y)}

Pengujian ini dimaksudkan untuk mengetahui distribusi normal seluruh data yang berhasil dikumpulkan. Dengan taraf nyata $\alpha=0,05$ dengan daerah penerimaan $\mathrm{H} 1$ ada dua, maka masing-masing daerah mempunyai luas $\alpha / 2=0,05 / 2=0,025$. Luas daerah $\alpha / 2=0,025$ untuk penolakan $\mathrm{H} 0$, maka luas daerah penerimaan $\mathrm{H} 1=0,5-$ $0,025=0,4750$.

Berdasarkan hasil pengujian, tidak ditemukan adanya nilai diluar dari angka ekstrim yaitu $( \pm 1,96)$, dapat dikatakan untuk variabel komitmen organisasi seluruh data yang berhasil dikumpulkan, layak dan berdistribusi normal.
Dari hasil pengujian instrument, juga dapat disimpulkan bahwa variabel kinerja karyawan tidak ada angka atau nilai yang menunjukkan adanya gejala outlier yaitu dalam rentang $( \pm 1,96)$. Hasil penelitian menunjukkan bahwa seluruh data variabel kinerja karyawan berdistribusi normal.

Hasil Uji Validitas dan Reliabilitas Instrumen Penelitian

Berdasarkan hasil perhitungan uji validitas dengan bantuan software SPSS versi 20.0, menunjukkan seluruh nilai rhitung diatas dari nilai kritis yaitu 0,3 dan juga lebih dari nilai t-tabel yaitu 0,338. Jika nilai r-hitung lebih besar dari nilai r-kritis $(0,3)$ maka item dinyatakan valid. Berdasarkan hasil penelitian ditemukan bahwa seluruh item yang terdapat pada variabel komitmen organisasi (X), dan kinerja karyawan (Y) memiliki nilai diatas $\mathrm{r}$ kritis $(0,3)$ dan nilai r-tabel $(0,338)$, sehingga item pernyataan dalam instrumen penelitian dinyatakan valid. Berdasarkan hasil uji reliabilitas instrumen, dapat disimpulkan bahwa instrumen yang digunakan untuk mengukur variabel komitmen organisasi $(\mathrm{X})$ dan kinerja karyawan (Y) adalah reliabel, karena nilai alpha cronbach semua variabel lebih dari nilai standar reliabilitas yaitu 0,60 (Ghozali, 2002).

\section{Rangkuman Analisis Deskriptif Tanggapan Responden terhadap Variabel Komitmen}

\section{Organisasi (X)}

\begin{tabular}{|c|l|l|c|}
\hline No. & \multicolumn{1}{|c|}{ Dimensi } & \multicolumn{1}{c|}{ Indikator } & Nilai (\%) \\
\hline $\mathbf{1}$ & Komitmen Afektif & Ikatan emosional karyawan & $\mathbf{7 6 , 5}$ \\
\hline $\mathbf{2}$ & Komitmen Berkelanjutan & Nilai atas pekerjaan yang digeluti & $\mathbf{8 8 , 7}$ \\
\hline $\mathbf{3}$ & Komitmen Normatif & Konsisten atas pekerjaan yang diemban & $\mathbf{8 8 , 2}$ \\
\hline
\end{tabular}

Berdasarkan nilai rata-rata tanggapan responden terhadap variabel komitmen organisasi dengan dimensi komitmen berkelanjutan tepatnya pada indikator nilai atas pekerjaan yang digeluti secara keseluruhan berpengaruh kuat sebesar $88,7 \%$. Hal ini menunjukkan bahwa hampir seluruh karyawan Perum BULOG Divre Kalsel setuju terhadap item yang menyatakan bahwa pekerjaan yang berarti memberikan 
pengalaman tersendiri bagi diri karyawan. Hasil penelitian senada dengan pernyataan dari Sunarto (2003) bahwa dengan adanya keterlibatan karyawan dalam setiap kegiatan operasional perusahaan memiliki kontribusi positif terhadap diri karyawan sendiri, dimana dengan adanya komitmen dalam pekerjaan membawa pada kepuasan kerja dan tingkat kualitas yang dimiliki oleh karyawan.

Hasil penelitian ini sesuai dengan pernyataan Mathieu dan Zajac (1990) dimana komitmen organisasi telah dikaitkan dengan beberapa variabel pribadi, peran suatu negara dan aspek lingkungan kerja mulai dari karakteristik pekerjaan sampai pada dimensi struktur organisasi. Hal senada juga dikemukakan oleh William dan Anderson (1991) dimana komitmen organisasi dipandang sebagai totalitas keyakinan terinternalisasi dan suatu perilaku yang bertanggung jawab serta mencerminkan pengorbanan pribadi demi organisasi, tidak tergantung terutama pada imbalan atau hukuman, dan menunjukkan loyalitas terhadap organisasi.

Hasil penelitian mendukung penelitan yang pernah dilakukan oleh Memari et al (2013), Rafiei et al (2014), serta Suliman dan Lles (2000), dengan meneliti pengaruh komitmen organisasi terhadap kinerja karyawan, yang dimana hasil dari penelitian mereka menunjukkan terdapat hubungan yang positif antara komitmen organisasi dan kinerja karyawan.

Hasil penelitian terhadap komitmen organisasi khususnya dimensi komitmen berkelanjutan dengan prosentase tertimggi mendukung teori yang dinyatakan oleh Allen dan Meyer (1990) dimana komitmen organisasi sebagai suatu konstruk psikologis yang merupakan karakteristik hubungan anggota organisasi dengan organisasinya dan memiliki implikasi terhadap keputusan individu dalam hal melanjutkan keanggotaannya dalam organisasi.

Rangkuman Analisis Deskriptif Tanggapan Responden terhadap Variabel Kinerja Karyawan (Y)

\begin{tabular}{|c|l|l|c|}
\hline No. & \multicolumn{1}{|c|}{ Dimensi } & \multicolumn{1}{|c|}{ Indikator } & Nilai (\%) \\
\hline $\mathbf{1}$ & Quality & Proses pekerjaan & $\mathbf{8 2 , 4}$ \\
\hline $\mathbf{2}$ & Quantity & $\begin{array}{l}\text { 1. Aktivitas produksi } \\
\text { 2. Hasil produksi }\end{array}$ & $\mathbf{7 6 , 5}$ \\
\hline $\mathbf{3}$ & Timeliness & Hasil akhir pekerjaan & $\mathbf{7 6 , 5}$ \\
\hline $\mathbf{4}$ & Cost Effectiveness & Penggunaan teknologi & $\mathbf{7 3 , 5}$ \\
\hline $\mathbf{5}$ & Need For Supervision & Fungsi pekerjaan & $\mathbf{7 3 , 5}$ \\
\hline $\mathbf{6}$ & Interpersonal Impact & Percaya diri & $\mathbf{8 5 , 3}$ \\
\hline
\end{tabular}

Berdasarkan nilai rata-rata tanggapan responden terhadap variabel kinerja karyawan dengan dimensi interpersonal impact tepatnya pada indikator kepercayaan diri karyawan secara keseluruhan berpengaruh kuat sebesar 85,3\%. Hal ini menunjukkan bahwa hampir seluruh karyawan Perum BULOG Divre Kalsel setuju terhadap item yang menyatakan pembagian tugas di tempat kerja (Perum
BULOG Divre Kalsel) membuat hubungan antar rekan kerja terjalin dengan baik. Hasil penelitian ini sesuai dengan yang dinyatakan oleh Sinambela (2012) dimana kinerja merupakan tanggung jawab setiap individu terhadap pekerjaan, membantu mendefinisikan harapan kinerja, mengusahakan kerangka kerja bagi supervisor dan pekerja untuk saling berkomunikasi. Pekerjaan memerlukan 
interaksi dengan rekan kerja dan atasan, mengikuti peraturan, dan kebijakan organisasi untuk dapat meningkatkan kepuasan kerja karyawan.

Menurut Gooleman (2007) dengan adanya hubungan baik, seseorang merasa lebih nyaman, terlibat, dimengerti dan saling percaya diantara mereka akan muncul serta jika seorang karyawan berada dalam suatu hubungan baik, mereka bisa menjadi lebih kreatif bersama-sama dan lebih efisien dalam membuat keputusan. Dalam rangka membangun interpersonal impact antar karyawan diperlukan komunikasi yang efektif, kepercayaan, kecerdasan emosional, dan keterbukaan satu sama lain. Hal senada juga dikemukakan oleh Maxwell (2001) dalam Kaswan (2012) membangun hubungan interpersonal yang baik antarkaryawan merupakan salah satu kunci keberhasilan di tempat kerja, dimana karyawan lebih kreatif dan lebih efisien dalam membuat keputusan disamping loyalitas yang kuat serta memiliki etika kerja untuk mewujudkan visi dan misi perusahaan.

Hasil penelitian diatas didukung oleh Sinambela (2012) yang menyatakan bahwa kinerja merupakan tanggung jawab setiap individu terhadap pekerjaan, membantu mendefinisikan harapan kinerja, mengusahakan kerangka kerja bagi supervisor dan pekerja untuk saling berkomunikasi. Hal senada juga dikemukakan oleh Bacal (1999) dimana kinerja merupakan proses komunikasi yang dilakukan secara terus-menerus dalam kemitraan antar karyawan dengan atasannya secara langsung.

Menjaga efektifitas optimal dari keberadaan sumber daya manusia harus dikelola secara berkelanjutan. Menurut Wibowo (2011) dalam menentukan tujuan dan sasaran kinerja maka hal yang pertama kali yang perlu dipertimbangkan adalah visi dan misi organisasi, penetapan tujuan dan sasaran perlu mempertimbangkan kompetensi yang dimiliki segenap sumber daya dalam organisasi. Kinerja merupakan perilaku nyata yang ditampilkan setiap orang sebagai prestasi kerja yang dihasilkan oleh karyawan sesuai dengan perannya dalam perusahaan.

\section{Analisis Regresi Sederhana}

Hasil uji Coefficients, pada bagian ini ditemukan nilai konstanta sebesar 20,039, nilai b sebesar 1,117 . Hasil perhitungan ini menyatakan bahwa jika tidak ada penambahan satu poin pada variabel bebas, maka kinerja karyawan adalah 20,039 dengan asumsi faktor lain dianggap konstan (ceteris paribus). Selain itu, nilai koefisien determinasi yang digunakan adalah $\mathrm{R}$ Square 0,61. Dengan kata lain, penelitian ini menunjukkan pengertian bahwa kinerja karyawan (Y) dipengaruhi oleh variabel independen komitmen organisasi sebesar $61 \%$, sedangkan sisanya $(100 \%-61 \%=$ $39 \%$ ) dijelaskan oleh faktor- faktor lain yang tidak termasuk atau berada di luar variabel penelitian.

a beta saham $<1$, Beta saham tertinggi selama periode penelitian yaitu sebesar 2.20 dimiliki oleh kode saham ADRO dengan nama perusahaan PT. Adaro Energy Tbk dan Beta saham terendah sebesar 0.13 dimiliki oleh kode saham UNTR denga nama perusahaan PT. United Tractors Tbk.

Rata-rata return saham syariah sebesar 2,65, return saham bisa positif bisa juga negatif, jika return saham negatif berarti mendapatkan kerugian atau capital lost dan jika return saham positif berarti mendapatkan keuntungan atau capital gain, semakin tinggi return saham tentunya akan semakin 
diharapkan karena dapat memberikan keuntungan yang maksimal. Return saham tertinggi sebesar 6.37 ada pada kode saham ADRO (PT. Adaro Energy Tbk ) ditahun 2015 dan return saham terendah sebesar 0,49 ada pada kode saham LPKR (PT. Lippo Karawaci Tbk).

\section{Hasil Pengujian Hipotesis \\ Hasil Uji Pengaruh Komitmen Organisasi (X) terhadap Kinerja karyawan (Y)}

Berdasarkan output hasil hitung menggunakan software SPSS didapat nilai thitung untuk variabel komitmen organisasi adalah 3,499 dan nilai ttabel adalah 1,692. Karena nilai thitung lebih besar dari ttabel maka dapat dikatakan bahwa komitmen organisasi berpengaruh positif dan signifikan terhadap kinerja karyawan.

Keterbatasan Penelitian

Penelitian ini berusaha mengisi kesenjangan pada penelitian sebelumnya namun beberapa keterbatasan masih terdapat dalam penelitian ini. Adapun keterbatasan yang dimaksud, antara lain: ruang lingkup penelitian yang terbatas, dari segi pengambilan sampel penelitian terdapat jumlah sampel yang sangat kecil yaitu hanya berjumlah 34 responden dari total karyawan Perum BULOG Divre kalsel yang berjumlah 51 orang. Selain itu, pada penelitian ini hanya mengambil satu variabel bebas (independen) yaitu komitmen organisasi satu variabel terikat (dependen) yaitu kinerja karyawan dengan uji analisis regresi linear sederhana.

Implikasi Hasil Penelitian

Implikasi Akademis

Penelitian yang telah dilakukan dengan berbagai proses dan tahapan yang jelas terhadap sebuah pemecahan masalah merupakan rangkaian penelitian ilmiah yang ditempuh oleh peneliti guna menarik suatu kesimpulan yang nyata atas gejala, fenomena, dan masalah yang diteliti.
Berkaitan dengan penelitian yang dilakukan oleh peneliti dengan mengangkat variabel penelitian yaitu komitmen organisasi dan kinerja karyawan.

Komitmen organisasi sebagai rasa identitas dari individu yang memiliki ketergantungan terhadap organisasi. Berdasarkan hasil penelitian yang telah dilaksanakan pada karyawan Perum BULOG Divre Kalsel Kota Banjarmasin terdapat pengaruh positif dan signifikan komitmen organisasi terhadap kinerja karyawan. Penelitian ini merupakan penelitian ilmiah dengan pemaparan bahasa yang mudah dipahami disertai berbagai struktur penelitian dan penggunaan metode penelitian secara sistematis dan jelas.

\section{Implikasi Manajerial}

Berdasarkan hasil penelitian diatas, beberapa bukti menunjukkan bahwa terdapat pengaruh positif dan signifikan komitmen organisasi terhadap kinerja karyawan. Kegiatan operasional dalam menjaga ketahanan pangan nasional yang bermutu dan memadai sesuai dengan tujuan didirikannya BULOG yaitu, dimana diperlukan adanya pengawasan ketika pelaksanaan kegiatan pendistribusian beras terlebih lagi beras yang diperuntukkan bagi warga miskin. Penelitian ini telah menghasilkan suatu model dengan melibatkan komitmen organisasi sebagai instrumen dalam rangka meningkatkan kinerja karyawan Perum BULOG Divre Kalsel Kota Banjarmasin. Selain itu, pihak BULOG Divre Kalsel perlu mengadakan koordinasi dan kerja sama dengan Pemerintah Daerah agar pengolahan data penerima manfaat dan pagu alokasi dapat sesuai dengan kenyataan dilapangan tanpa terjadi penyimpangan. Dengan berbagai perbaikan yang dilakukan mulai dari ketepatan data dan sasaran penerima manfaat serta harga yang ditawarkan kepada warga 
miskin dapat mempermudah dalam kegiatan pendistribusian beras.

\section{KESIMPULAN DAN SARAN}

\section{Kesimpulan}

Berdasarkan hasil temuan penelitian dan pembahasannya, maka secara garis besar dapat di tarik kesimpulan, dimana komitmen organisasi berpengaruh positif dan signifikan terhadap kinerja karyawan Perum BULOG Divisi Regional Kalimantan Selatan Kota Banjarmasin. Pengaruh positif dan signifikan memiliki makna bahwa ketika komitmen karyawan terhadap organisasi meningkat maka kinerja karyawan juga akan meningkat dan sebaliknya. Pengaruh positif menunjukkan bahwa semakin meningkat komitmen karyawan terhadap organisasi, baik dilihat dari segi komitmen afektif, berkelanjutan, dan normatif maka hal ini akan meningkatkan kinerja karyawan.

\section{Saran}

\section{Saran Akademis}

1. Memperkaya konsep baru mengenai pengembangan teori komitmen organisasi serta pengaruhnya terhadap kinerja karyawan.

2. Rekomendasi dan saran ditujukan kepada peneliti lanjutan terutama dalam pengembangan model dan teori yang selalu update sesuai dengan kebutuhan peneliti terhadap fenomena dan gejala di lapangan yang dihadapi.

3. Perlu melakukan kegiatan uji coba yang lebih luas baik dari kelompok sasaran, lokasi dan siklusnya sehingga model penelitian yang akan datang memiliki validitas dan reliabilitas yang lebih handal.

4. Mengangkat penelitian dengan jumlah sampel yang banyak dan ruang lingkup penelitian yang lebih luas dengan alat uji statistik yang berbeda.
5. Melakukan penelitian dengan variabel yang berbeda atau dengan menambahkan variabel lain dalam menganalisis faktor yang mempengaruhi kinerja karyawan.

\section{Saran Manajerial}

6. Adapun saran yang diperuntukkan bagi pihak Perum BULOG Divre Kalsel Kota Banjarmasin, antara lain:

7. Bentuk komitmen karyawan terhadap organisasi dalam meningkatkan kinerja dapat dilihat dari pelaksanaan sosialisasi secara berjenjang, monitoring dan evaluasi, serta pengawasan pelaksanaan distribusi Raskin agar diterima oleh RTS sesuai prisip 6T (Tepat Pengelolaan dan Pengorganisasian, Tepat Perencanaan dan Penganggaran, Tepat Mekanisme Pelaksanaan, Tepat Pengendalian dan Pelaporan serta Sosialisasi). Komitmen karyawan terhadap organisasi menjadi faktor penting dimana hal ini berkaitan erat dengan konsistensi terhadap pekerjaan yang digeluti oleh karyawan.

8. Pelaksanaan briefing pagi hendaknya perlu dilakukan dengan intens, hal ini bertujuan untuk meminimalisir karyawan yang datang terlambat. Selain itu, perlu adanya pemberian reward atau penghargaan kepada karyawan yang selalu datang tepat waktu dengan tingkat produktivitas kerja yang tinggi.

9. Perlu adanya pengawasan terhadap seluruh kegiatan operasional di lapangan baik kegiatan distribusi, penetapan harga jual raskin, dan data penerima raskin yang tepat maupun kegiatan administrasi. Hal ini bertujuan untuk menyeleraskan antara perencanaan dan tujuan yang ditetapkan oleh Perum BULOG Divisi Regional Kalimantan Selatan.

\section{DAFTAR PUSTAKA}

Ali, F., Karamat M., Noreen H., Khurram M., Chuadary A., Nadeem M., et al. 
(2011). The effect of Job Stress and Job Performance on Employee's Commitment. European Journal of Scientific Research, vol. 60, no. 2, pp. 285-294.

Allen, N. J., dan Meyer, J. P. (1990). The measurement and antecedents of affective, continuance and normative commitment to the organization. Journal of Occupational Psychology, vol. 63, no. 1, pp. 1-18.

Bacal, Robert (1999). Performance Management. New York: McGraw Hill Companies, Inc.

Cooper, Donald R. dan Schindler Pamela S. (2006). Business Research Methods Ninth Edition. America, New York: Mc. Graw Hill Griwn, Companies.

Ghozali, Imam (2002). Aplikasi Analisis Multivariat dengan Program SPSS. Semarang: Badan Penerbit Universitas Diponegoro.

Gooleman, Daniel (2007). Working with Emotional Intelligence (Kecerasan Emosi Untuk Mencapai Puncak Prestasi). Jakarta: Gramedia.

Kaswan (2012). Manajemen Sumber Daya Manusia untuk keunggulan Bersaing Organisasi. Yogyakarta: Graha Ilmu.

Mathieu, J. E., dan Zajac, D. M. (1990). A Review and Meta-analysis of the Antecedents, Correlates, and Consequences of Organizational Commitment. Psychological Bulletin, vol. 108, pp. $171-94$.

Memari, Negin, Omid M., dan Ahmad B.M. (2013). The Impact of Organizational Commitment on Employees Job Performance. Interdisciplinary Journal of Contemporary Research in Business, vol. 5, no. 5, pp. 164-171.

Meyer, John P., Becker Thomas E., dan Vandenberghe C. (2004). Employee Commitment and Motivation: A Conceptual Analysis and Integrative Model. Journal of Applied Psychology, vol. 89, no. 6, pp. 991-1007.

Rafiei, M., Mohammad T.A., dan Navid F (2014). Studying the impact of the organizational commitment on the job performance. Journal of Management Science Letters, vol. 4, pp. 1841-1848.

Rivai, Veithzal dan A.F. Mohd. Basri (2005). Performance Appraisal. Jakarta: PT RajaGrafindo Persada.

Robbins, Stephen P. dan Judge, Timothy A. (2008). Perilaku Organisasi (Organizational Behavior). Jakarta: Salemba Empat.

Sinambela, Lijan Poltak (2012). Kinerja Pegawai (Teori Pengukuran dan Implikasi). Yogyakarta: Graha Ilmu.

Suliman, A.M.T. dan Lles, P. (2000). Is continuance commitment beneficial to organizations? Commitment performance relationship: a new look. Journal of Managerial Psychology, vol. 15, no. 5, pp. 407-426.

Sunarto (2003). Perilaku Organisasi. Yogyakarta: AMUS Yogyakarta dan Mahenoko Total Design Yogyakarta.

Susanty, Aries dan Miradipta, Rizqy (2013). Employees Job performance: The Effect of Attitude Toward Works, Organizational Commitment, and Job Satisfaction. Journal Teknik Industri, vol. 15, no. 1, pp. 13-23.

Thoha, Miftah (1983). Perilaku Organisasi Konsep Dasar dan Aplikasi. Jakarta: Rajawali Pers.

Wibowo (2011). Manajemen Kinerja. Jakarta: PT RajaGrafindo Persada.

William, J. Larry dan Anderson, Stella E. (1991). Job Satisfaction and Organizational Commitment as Predictor of Organizational Citizenship and In Role Behaviors. Journal of Management, vol. 17, no. 3, pp. 601617. 